\title{
Seasonal Diagenetic Changes in Trace Metals Levels of a Brackish Water System in the Niger Delta, Nigeria
}

\author{
${ }^{1}$ Marcus, A C and ${ }^{2}$ Nwoke, I B \\ Department of Chemistry, Ignatius Ajuru University of Education, P.M.B. 5047, Rumuolumeni, Port Harcourt, \\ Nigeria
}

\begin{abstract}
The concentrations of mercury, lead, nickel, vanadium and cadmium of a brackish water system in the Niger Delta were assessed in order to determine seasonal diagenetic changes and how such changes affect their correlations with water quality parameters. Nine locations were sampled at two monthly intervals for a period of one year. Solvent extraction using ammonium pyrrolidine dithiocarbamate (APDC) and methyl isobutyl ketone (MIBK) was employed for the extraction of trace metals. Buck scientific model 200A Atomic Absorption Spectrophotometer and air-acetylene flame were used for their analyses, except for mercury, which was analyzed by cold vapour technique. Water quality parameters were determined using appropriate meters and various standard methods. The results of the analyses showed ranges of concentrations (ppb) of trace metals as follows: $\mathrm{Hg}$ (BDL-1.25), $\mathrm{Pb}$ (0.13-131.13), $\mathrm{Ni}$ (0.28-246.80), $\mathrm{V}$ (BDL-1.18) and Cd (0.28-24.63). There were significant $(p<0.05)$ seasonal differences for $\mathrm{Pb}$ and $\mathrm{Cd}$. Two-way analysis of variance also showed significant ( $p<0.05)$ spatial variations in both dry and wet seasons. Total alkalinity $(\mathrm{TA}), \mathrm{Mg}^{2+}, \mathrm{K}^{+}$, and $\mathrm{Na}^{+}$ revealed significant $(p<0.05)$ seasonal variations with respect to higher values in the wet season. Significant $(p<0.05)$ correlation coefficients between $\mathrm{PO}_{4}{ }^{3-}$ and $\mathrm{Pb}, \mathrm{V}$ and $\mathrm{Cd}$ in the dry season, an indication that these metals were probably in their phosphates and as particulates, was observed, but the observation in the wet season was different, suggesting seasonal diagenetic differences. Also, apart from direct discharge of industrial and domestic wastes, the immense volume of storm water runoff and river waters entering this water system may have played major roles in transporting metals originating from wastes discharge on land and in small streams, especially during the rains. This phenomenon may have resulted in elevated levels of lead and cadmium in the water column in wet season.
\end{abstract}

BDL: Below Detection Limit

Keywords: seasonal diagenetic differences, solvent extraction, correlation coefficients, brackish water system, Niger Delta

\section{Introduction}

Trace metals are among the most common environmental pollutants, and their occurrence in waters and biota is in most cases, an implication for natural or anthropogenic sources. The main natural sources of metals in waters are chemical weathering of minerals and soil leaching. The anthropogenic sources are associated mainly with industrial and domestic effluents, urban storm, water runoff, landfill leachate, mining of coal and ore, atmospheric sources and inputs from rural areas (Kabata-Pendias and Pendias, 1992; Biney et. al., 1994; Zarazua et. al., 2006).

The existence of trace metals in aquatic environments has led to serious concerns about their influence on plant and animal life. Exposure to elevated concentrations can cause organisms to die. Metals such as $\mathrm{Pb}, \mathrm{Cd}$, etc., exhibit extreme toxicity even at trace levels (Nicolau et. al., 2006). The concentrations at which metals are considered important vary as some are essential at low concentrations and toxic at higher levels.

The behaviour of metals in natural waters is a function of the substrate sediment composition, the suspended sediment composition, and the water chemistry (Osmond et. al., 1995). During their transport, the trace metals undergo numerous changes in their speciation due to dissolution, precipitation, sorption and complexation phenomena (Dassenakis et. al., 1997; Akcay et. al., 2003) which affect their behaviour and bioavailability (Nicolau et. al., 2006).

Trace metals may be sensitive indicators for monitoring changes in the water environment, and with increasing public concern regarding environmental contamination by them, there is also a growing need to monitor, manage and remediate ecological damage (Jarup, 2003, Silva et. al., 2005). The concentration of metals in surface water depends on several factors like soil dust, local point sources, natural presence in bedrock and soils, and airborne contribution from long range transport (Frank and Cross, 1974; Pan and Brugam, 1997). In addition, conditions in the catchments and lake are important for the mobility and availability of metals in the water. Rivers and lakes are exposed to atmospheric deposition of anthropogenically derived trace elements. This can create harmful effects on environmental condition and human health due to their toxicity and 
bioaccumulation in various environmental compartments (Boyd and Tucker, 1998; Jarup, 2003, Silva et. al., 2005).

There are also quite a number of studies on the physicochemical quality of river waters in literature (Okoye, 1991; Otokunefor and Obiukwu 2005; Sithik et. al., 2009; Garg et. al., 2010). Disposal of untreated wastes, discharge of chemicals, uncontrolled land use and agricultural activities are examples of water quality deterioration. Other activities concerning hydrological, hydrogeological and hydraulic activities (e.g. construction of dams, ground-water over pumping) also result in long-term environmental degradation. In addition to anthropogenic influences on water quality degradation, natural events (e.g. mud flow, hurricanes, torrential rainfall) can lead to deterioration of the aquatic environment. Rainfall in particular, is often the largest single variable affecting the quantity of water; although it normally undergoes only a low level of treatment, it may occasionally over-load the entire system (UNEP, 1992).

Reports on temporal changes, especially seasonal variations, in trace metal concentrations in river waters have been of interest in recent times (Iwashita and Shimamura, 2003). This is one of such attempts to obtain information on the variations of seasonal characteristics in order describe seasonal diagenetic changes in the relationship between water quality parameters and the levels of $\mathrm{Hg}, \mathrm{Pb}, \mathrm{Ni}, \mathrm{V}$ and $\mathrm{Cd}$ in the water column of Bonny River and creeks around Okrika, a brackish water system.

\section{Study Area}

\section{Materials And Methods}

The studied area is in Okrika Local Government Area of Rivers State, Nigeria. It is a riverine and intertidal wetland which lies on the north bank of the Bonny River, about 35 miles $(56 \mathrm{~km})$ upstream from the Bight of Benin in the Eastern Niger Delta of Nigeria. A maze of rivers and winding creeks intersect it, and within it are, stretches of marshy land having mangrove trees with thickets of tangled roots as the vegetation. The tidal amplitude of the eastern Niger Delta is between 1.5 to $2 \mathrm{~m}$ in normal tide, and the water level increases and decreases depending on the lunar cycle (Chindah et. al., 2004).

Rainfall in the coastal belt of the area, of which Okrika is a major part, usually starts from March, reaching the peak between June/August and ending in November. It is usually heavy due to the closeness of the Delta region to the equator. Between December and February, there are usually occasional showers. Annual rainfall totals vary from 2400 to over 4000 cubic meters. Consequently, the river banks and beaches are constantly eroded by perennial flooding, the scouring of the sea due to natural causes, and marine or navigation activities; there has also been severe loss of land and so, flood control measures have been very minimal.

There is also salt water intrusions from sea water into the rivers with the result that to obtain portable water; boreholes must be sunk to a depth of several hundred feet to avoid the possibility of picking salt-water interface (Abam, 1999). Nine sampling locations as described in table 1 and figure below, chosen for the study all of which are tributaries of Bonny River, are also connected to the Port Harcourt Refinery Outfall making thus the area a potential recipient of process wastewater from the company.

Table 1: Description of sample locations and their codes

\begin{tabular}{|l|l|l|}
\hline S/N & Location & Description \\
\hline 1 & EKC & Ekerekana Creek \\
\hline 2 & OKC & Okochiri Creek \\
\hline 3 & OOC & Okari/Okpaku creek \\
\hline 4 & OBR & Okrika/Bonny River \\
\hline 5 & OGR & Ogoloma River \\
\hline 6 & GAC & George Ama Creek \\
\hline 7 & IBC & Ibaka Creek \\
\hline 8 & OTR & Okpoka-Toru or Okpoka River \\
\hline 9 & OAC & Oba Ama Creek \\
\hline
\end{tabular}




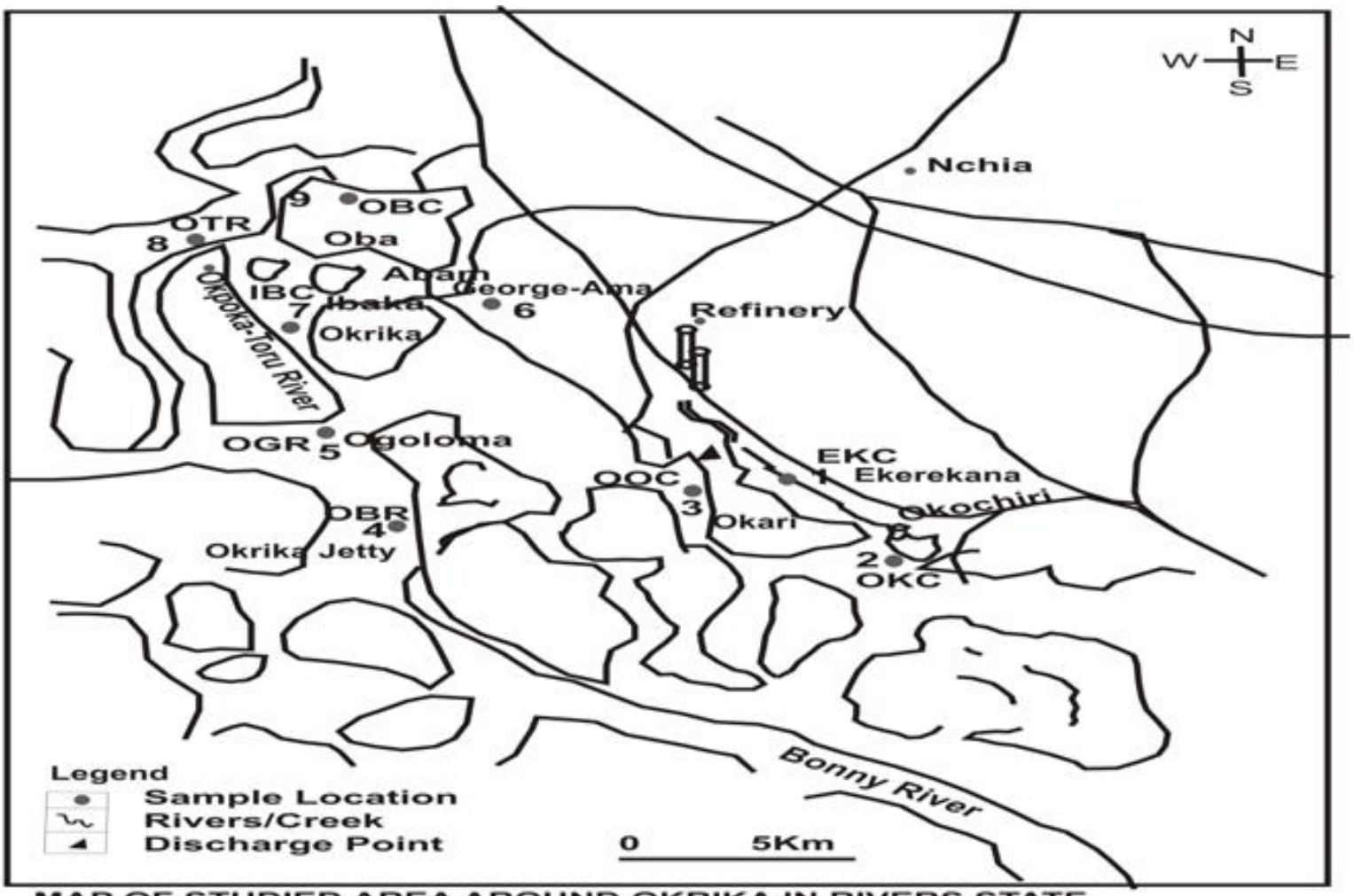

MAP OF STUDIED AREA AROUND OKRIKA IN RIVERS STATE

SHOWING SAMPLED RIVERS AND CREEKS

\section{Samples collection, treatment and analysis}

Water samples were collected below the surface film with pre-rinsed 1-litre plastic containers for the analysis of physicochemical parameters and trace metals. Deep-freezing was used as the method of sample preservation since it allows only the least changes in the sample during storage.

Samples for trace metals analyses in water were treated with $2 \mathrm{ml}$ conc. nitric acid prior to storage in order to maintain stable oxidation states of the metals in frozen condition, and also to avoid adsorption of metals on the container, before laboratory analysis (APHA, 1992). Those for biological oxygen demand (BOD5), chemical oxygen demand (COD) and dissolved oxygen (DO) were collected in $250 \mathrm{ml}$ glass stoppered reagent bottles. The BOD5 samples were carefully filled without trapping in air and the bottles wrapped with dark polythene bags and incubated for 5 days, to exclude all light, the presence of which is capable of producing DO by autotrophes (algae) presumably present in the sample. Dissolved oxygen (DO) samples were fixed up on the spot with Winkler solutions I and II. The COD samples were acidified with tetraoxosulphate (VI) acid (APHA, 1998).

Solvent extraction using ammonium pyrrolidine dithiocarbamate (APDC) and methyl isobutyl ketone (MIBK) was employed for preparation of water samples for trace metals. The water samples for analysis of the major cations were prepared by acid digestion using 1:3:1 mixture of $\mathrm{HC} 1 \mathrm{O} 4, \mathrm{HNO} 3$ and $\mathrm{H} 2 \mathrm{SO} 4$ acids. Buck Scientific atomic absorption spectrophotometer model 200A and air-acetylene flame were used for all trace metal analyses, except for mercury which was by the cold vapour method using sodium borohydride $\left(\mathrm{NaBH}_{4}\right)$ in a mercury kit and vapour allowed to go into the AAS instrument without flame.

\section{Water quality parameters}

Water $\mathrm{pH}$ was determined using a multi parameter HARCH sensor 156, temperature by dipping a mercury in glass thermometer (British standard BS593), salinity using a Hanna membrane millimeter digital scan meter (H8314mmodel), conductivity using a scan conductivity meter, model 1560, total hardness by complexometric titration, Total alkalinity by titration with $\mathrm{HCl}$, COD (Titrimetry), DO, $\mathrm{BOD}_{5}$, by Winkler's method, Total suspended solids and Total dissolved solids by Gravimetry, Turbidity, silicate and nitrate by colorimetric method, sulphate by turbidimetric method phosphate by stannous chloride method, calcium and magnesium by EDTA titrimetry, and sodium and potassium by flame photometry (APHA, 1998; ASTM, 2005). 
Results

\section{Results And Discussion}

Trace metal levels (ppb) in the unfiltered surface water samples are presented in Table 2.

Table 2 Mean seasonal values $(\mathrm{n}=6)$ of trace metals ( $\mathrm{ppb})$ in the brackish water system

\begin{tabular}{|l|l|l|}
\hline Metal & Dry Season & Wet Season \\
\hline $\mathrm{Hg}$ & BDL & BDL \\
\hline $\mathrm{Pb}$ & $(0.73-76.00) 16.45 \pm 23.49$ & $(0.98-131.13) 27.51 \pm 34.01$ \\
\hline $\mathrm{Ni}$ & $(0.50-246.80) 46.48 \pm 68.19$ & $(0.28-210.50) 31.8 \pm 53.69$ \\
\hline $\mathrm{V}^{*}$ & $(0.28-1.00) 0.11 \pm 0.24$ & $(0.28-1.18) 0.20 \pm 0.34$ \\
\hline $\mathrm{Cd}$ & $(0.23-20.25) 1.87 \pm 3.52$ & $(0.28-24.63) 7.03 \pm 7.57$ \\
\hline
\end{tabular}

BDL: Below detection limits. Levels are ranges and means \pm sd. * Detectable values only

The table shows that mercury was not detectable in both seasons. Vanadium was however, only detectable in six samples from six different locations in the dry season, representing about $20 \%$ of the total number of samples collected in that season. In the wet season, it was detectable in ten samples also from six different locations, and this represents about $33.33 \%$ of the total number of samples analyzed in the season. Lead, nickel and cadmium were on the other hand, detectable in all samples from the nine locations during the two seasons. Results of recovery analysis using Standard Material (CASS-4) for the trace metals are as follows: cadmium $(76.92 \%)$, lead $(79.59 \%)$, nickel $(96.82 \%)$, and vanadium $(94.75 \%)$. These could be considered favourable for trace metals analysis in water. The detection limits (ppm) for all the trace metals are as follows: lead (0.05), nickel (0.02), vanadium (0.2) and cadmium (0.002).

All the metals show higher mean values in the wet season, except nickel, which was lower in the same season. Two-way analysis of variance also showed significant $(\mathrm{p}<0.05)$ spatial variations in concentrations in both dry and wet seasons, while correlation coefficients of only the pair of $\mathrm{Ni}$ and $\mathrm{Pb}$ is significant $(\mathrm{p}<0.05)$ as shown in Table 3, suggesting that the two metals have a common source.

Table 3 Correlations matrices for the combined trace metals data of the brackish water system

$\begin{array}{llllll} & \mathrm{Hg} & \mathrm{Pb} & \mathrm{Ni} & \mathrm{V} & \mathrm{Cd} \\ \mathrm{Hg} & 1 & & & & \\ \mathrm{~Pb} & -1^{* *} & 1 & & & \\ \mathrm{Ni} & 1 & 0.259122^{*} & 1 & 1 & \\ \mathrm{~V} & - & 0.118662 & -0.14344 & 1 & \\ \mathrm{Cd} & 1^{* *} & 0.227965 & 0.037272 & -0.01078 & 1\end{array}$

. **Correlation is significant at the 0.01 level (2-tailed) *Correlation is significant at the 0.05 level (2-tailed). Tables $4 \mathrm{a}$ and $4 \mathrm{~b}$ present average seasonal values of physicochemical parameters

Table 4a Mean levels of physico-chemical parameters of the brackish water system in the dry season

\begin{tabular}{|c|c|c|c|c|c|c|}
\hline \multirow{2}{*}{$\begin{array}{l}\text { Sample } \\
\text { Location }\end{array}$} & \multicolumn{6}{|l|}{ Parameters } \\
\hline & $\mathrm{pH}$ & Temperature $\left({ }^{\circ} \mathrm{C}\right)$ & Total Dissolved Solids (mgL) & Salinity $(\mathrm{mg} \mathrm{L}$ ) & Conductivity $\left(\mu \mathrm{scm}^{-2}\right)$ & $\begin{array}{l}\text { Total Hardness } \\
(\mathrm{Ca}+\mathrm{Mg})(\mathrm{mg}) \mathrm{L})\end{array}$ \\
\hline EKC & $7.15=0.10$ & $27.93=0.64$ & $17,036.67=309.89$ & $8,400.00=229.13$ & $33,473.33=1314.58$ & $118.06=79.19$ \\
\hline $\mathrm{OKC}$ & $7.40=0.08$ & $27.37=0.40$ & $32,885.00=248.34$ & $16,150.00=975.96$ & $63,100.00=1997.50$ & $149.63=7.76$ \\
\hline $\mathrm{OOC}$ & $7.50=0.06$ & $27.03=0.42$ & $35,016.67=1,027.54$ & $17.250 .00=409.27$ & $66.510 .00=704.50$ & $169.65=2.44$ \\
\hline$\overline{O B R}$ & $7.57=0.05$ & $26.63=0.23$ & $32.968 .33=237.19$ & $16,116.67=857.81$ & $63,566.67=2157.16$ & $170.89=9.94$ \\
\hline OGR & $7.55=0.06$ & $27.03=0.21$ & $35,166.67=611.01$ & $17,066.67=152.75$ & $65,900.00=2722.13$ & $172.39=16.91$ \\
\hline GAC & $7.71=0.04$ & $27.20=0.62$ & $34,066.67=1,006.64$ & $16,866.67=208.17$ & $65,280.00=769.22$ & $139.08=31.28$ \\
\hline IBC & $7.56=0.05$ & $26.83=0.31$ & $33,066.67=351.19$ & $16,383.33=381.88$ & $64,083.33=225.46$ & $167.47=10.38$ \\
\hline OTR & $7.72=0.03$ & $26.90=0.36$ & $33,266.67=288.68$ & $16,566.67=305.51$ & $65,026.67=328.84$ & $169.21=12.41$ \\
\hline $\mathrm{OAC}$ & $2.29=0.02$ & $26,53=0.25$ & $25,816.67=768.66$ & $13,050.00=1,033.20$ & $47,566.67=1075.98$ & $155.95=13.39$ \\
\hline Range & $(7.05-7.75)$ & $(26.50-28.60)$ & $(445-35,700)$ & $(226-17,600)$ & $(789-67,900)$ & $(9.12-191.10)$ \\
\hline Ov.mean $=\mathrm{Sd}$ & $7.47=0.19$ & $27.18=0.62$ & $27,975.67=10,786.48$ & $13,791.47=5,333.83$ & $53,532.50=20,657.89$ & $145.45=54.25$ \\
\hline
\end{tabular}

Table 4a Mean levels of physico-chemical parameters of the brackish water system in the dry season-contd

\begin{tabular}{|c|c|c|c|c|c|c|c|}
\hline $\begin{array}{l}\text { Sample } \\
\text { Location }\end{array}$ & $\begin{array}{l}\text { Total Alkalinity } \\
(\mathrm{mgl})\end{array}$ & $\begin{array}{l}\text { Biological Oxygen } \\
\text { Demand }(m g L)\end{array}$ & $\begin{array}{l}\text { Chemical Oxygen } \\
\text { Demand (mgL) }\end{array}$ & $\begin{array}{l}\text { Dissolved } \\
\text { Oxygen (mgL) }\end{array}$ & $\begin{array}{l}\text { Total Suspended } \\
\text { Solids }(\mathrm{mg} L)\end{array}$ & Turbidity (NTU) & $\begin{array}{l}\mathrm{SiO}_{2}^{+-} \\
(\mathrm{mg} \mathrm{L})\end{array}$ \\
\hline EKC & $88.07=18.18$ & $76.67=4.98$ & $100.97=2.29$ & $3.23=0.01$ & $26.63=3.80$ & $18.40=2.00$ & $2.39=0.53$ \\
\hline $\mathrm{OKC}$ & $98.00=26.85$ & $39.57=0.57$ & $49.70=4.58$ & $3.23=1.00$ & $28.33=1.70$ & $21.77=1.11$ & $2.69=0.09$ \\
\hline $\mathrm{OOC}$ & $125.27=5.83$ & $38.00=5.41$ & $46.50=1.21$ & $3.40=0.93$ & $34.27=3.91$ & $18.70=0.56$ & $3.00=0.38$ \\
\hline OBR & $98.10=13.78$ & $43.17=10.90$ & $51.60=1.37$ & $3.98=0.81$ & $20.10=10.15$ & $9.50=0.98$ & $2.87=0.08$ \\
\hline OGR & $45.57=56.67$ & $32.90=0.96$ & $35.70=3.84$ & $3.74=0.33$ & $12.83=2.10$ & $15.50=3.00$ & $2.57=0.60$ \\
\hline $\mathrm{GAC}$ & $108.90=7.91$ & $25.20=5.29$ & $25.77=1.68$ & $4.01=0.65$ & $11.63=1.53$ & $14.13=0.95$ & $2.66=0.29$ \\
\hline IBC & $127.20=1.39$ & $20.40=0.70$ & $26.33=2.53$ & $4.04=0.24$ & $5.93=3.20$ & $7.50=1.85$ & $2.57=0.26$ \\
\hline OTR & $80.47=56.70$ & $20.53=2.01$ & $25.40=1.32$ & $4.15=0.40$ & $3.47=0.76$ & $6.63=0.80$ & $3.14=0.07$ \\
\hline OAC & $92.77=15.00$ & $11.37=0.86$ & $18.23=2.06$ & $3.78=0.65$ & $5.10=1.11$ & $3.87=0.59$ & $2.85=0.13$ \\
\hline Range & $(6.90-132.00)$ & $(10.60-77.30)$ & $(16.10-102.80)$ & $(2.28-4.72)$ & $(2.80-38.59)$ & $(3.20-22.80)$ & $(0.01-3.25)$ \\
\hline Ov.mean $=\mathrm{Sd}$ & $89.81=39.53$ & $37.35=20.20$ & $45.43=24.92$ & $3.70=0.64$ & $16.14=10.83$ & $13.04=5.58$ & $2.48=0.87$ \\
\hline
\end{tabular}


Seasonal Diagenetic Changes in Trace Metals Levels of a Brackish Water System in the Niger ....

Table 4a Mean levels of physico-chemical parameters of the brackish water system in the dry season-contd

\begin{tabular}{|l|l|l|l|l|l|l|l|}
\hline $\begin{array}{l}\text { Sample } \\
\text { location }\end{array}$ & $\begin{array}{l}\mathrm{NO}_{3}{ }^{-} \\
(\mathrm{mg} / \mathrm{L})\end{array}$ & $\begin{array}{l}\mathrm{SO}_{4}{ }^{2-} \\
(\mathrm{mg} / \mathrm{L})\end{array}$ & $\begin{array}{l}\mathrm{PO}_{4}{ }^{3-} \\
(\mathrm{mg} / \mathrm{L})\end{array}$ & $\begin{array}{l}\mathrm{Ca}^{2+} \\
(\mathrm{mg} / \mathrm{L})\end{array}$ & $\begin{array}{l}\mathrm{Mg}^{2+} \\
(\mathrm{mg} / \mathrm{L})\end{array}$ & $\begin{array}{l}\mathrm{Na}^{+} \\
(\mathrm{ppm})\end{array}$ & $\begin{array}{l}\mathrm{K}^{+} \\
(\mathrm{mg} / \mathrm{L})\end{array}$ \\
\hline EKC & $0.01 \pm 0.00$ & $20.27 \pm 3.37$ & $0.27 \pm 0.35$ & $37.85 \pm 1.53$ & $2.92 \pm 0.13$ & $10.51 \pm 1.04$ & $5.76 \pm 2.77$ \\
\hline OKC & $0.84 \pm 0.59$ & $25.20 \pm 3.40$ & $0.19 \pm 0.14$ & $54.42 \pm 0.26$ & $2.97 \pm 0.14$ & $9.89 \pm 0.61$ & $8.49 \pm 0.35$ \\
\hline OOC & $1.20 \pm 0.76$ & $23.63 \pm 0.50$ & $0.19 \pm 0.02$ & $62.74 \pm 0.70$ & $2.95 \pm 0.04$ & $10.45 \pm 0.12$ & $8.45 \pm 0.35$ \\
\hline OBR & $1.17 \pm 0.48$ & $25.17 \pm 1.40$ & $0.21 \pm 0.01$ & $57.44 \pm 2.10$ & $2.93 \pm 0.04$ & $10.05 \pm 0.41$ & $8.49 \pm 0.61$ \\
\hline OGR & $1.32 \pm 0.14$ & $26.01 \pm 2.94$ & $0.72 \pm 0.93$ & $61.79 \pm 0.24$ & $2.59 \pm 0.45$ & $9.62 \pm 0.29$ & $8.66 \pm 0.14$ \\
\hline GAC & $1.18 \pm 0.42$ & $23.20 \pm 0.52$ & $0.87 \pm 1.09$ & $51.78 \pm 6.62$ & $2.92 \pm 0.05$ & $10.66 \pm 0.73$ & $8.23 \pm 0.34$ \\
\hline IBC & $1.40 \pm 0.20$ & $24.57 \pm 0.59$ & $0.75 \pm 0.83$ & $60.66 \pm 0.54$ & $2.81 \pm 0.13$ & $10.64 \pm 0.53$ & $8.47 \pm 1.48$ \\
\hline OTR & $1.48 \pm 0.23$ & $26.27 \pm 2.48$ & $0.33 \pm 0.08$ & $60.11 \pm 0.54$ & $2.77 \pm 0.23$ & $10.05 \pm 0.94$ & $8.41 \pm 0.66$ \\
\hline OAC & $0.51 \pm 0.02$ & $21.97 \pm 0.64$ & $0.18 \pm 0.02$ & $54.52 \pm 0.56$ & $2.90 \pm 0.09$ & $9.64 \pm 0.66$ & $8.41 \pm 0.19$ \\
\hline $\begin{array}{l}\text { Range } \\
\text { Ov.mean } \pm S d\end{array}$ & $\begin{array}{l}\text { BDL-1.740) } \\
0.98 \pm 0.55\end{array}$ & $(10.70-28.70)$ & $(0.02-2.13)$ & $(2.47-63.41)$ & $(1.52-3.12)$ & $(7.00-11.43)$ & $(2.14-9.97)$ \\
\hline
\end{tabular}

Table 4b Mean levels of physico-chemical parameters of the brackish water system in the wet season

\begin{tabular}{|c|c|c|c|c|c|c|}
\hline \multirow{2}{*}{$\begin{array}{l}\text { Sample } \\
\text { Location }\end{array}$} & \multicolumn{6}{|l|}{ Parameters } \\
\hline & $\mathrm{pH}$ & Temperature $\left({ }^{\circ} \mathrm{C}\right)$ & Total Dissolved Solids (mgL) & Salinity $(\mathrm{mg} / \mathrm{L})$ & Conductivity $\left(\mu \mathrm{s} \mathrm{cm}^{-2}\right)$ & $\begin{array}{l}\text { Total Hardness } \\
(\mathrm{Ca}+\mathrm{Mg})(\mathrm{mg})\end{array}$ \\
\hline EKC & $6.87=0.05$ & $26.70=0.46$ & $15,415.00=410.09$ & $7.914 .00=255.91$ & $30.578 .00=886.55$ & $70.30=74.86$ \\
\hline OKC & $7.88=0.07$ & $27.17=0.42$ & $27,304.67=870.10$ & $13,466.67=1,365.04$ & $54,976.67=297.38$ & $149.59=1.59$ \\
\hline OOC & $7.62=0.67$ & $27.07=0.47$ & $27,777.33=807.43$ & $13,900.00=360.56$ & $54.273 .33=933.88$ & $174.41=8.45$ \\
\hline OBR & $7.73=0.06$ & $26.87=0.67$ & $27,813.33=1,036.60$ & $14,033.33=404.15$ & $54,400.00=2,137.76$ & $177.48=10.50$ \\
\hline OGR & $7.87=0.15$ & $27.23=0.59$ & $31,100.00=5,200.00$ & $14,000.00=435.89$ & $58,716.67=5,833.17$ & $166.32=16.48$ \\
\hline GAC & $7.25=0.28$ & $27.37=0.55$ & $31,933.33=5,063.92$ & $17,200.00=608.28$ & $60,050.00=8,463.30$ & $155.55=11.24$ \\
\hline IBC & $8.00=0.17$ & $27.10=0.26$ & $33,516.67=4,417.11$ & $16,700.00=871.78$ & $62,066.67=3,807.01$ & $174.68=13.03$ \\
\hline OTR & $7.47=0.42$ & $26.80=0.10$ & $33,240.00=1,566.14$ & $16,583.33=1,277.04$ & $63,133.33=3,894.01$ & $169.28=14.85$ \\
\hline $\mathrm{OAC}$ & $7.25=0.28$ & $27.40=0.26$ & $26,836.67=1,565.58$ & $13,900.00=1,558.85$ & $49,733.33=5,115.99$ & $163.75=16.75$ \\
\hline Range & $(6.42-8.20)$ & $(26.10-27.90)$ & $(234-37,100)$ & $(127-17,900)$ & $(430-67,300)$ & $(8.42-189.60)$ \\
\hline Ov.mean $=S d$ & $7.44=0.52$ & $27.08=0.43$ & $24,702.87=11,003.99$ & $12,776.60=5,032 . .70$ & $48,837=18,998.03$ & $144.18=59.26$ \\
\hline
\end{tabular}

Table 4b Mean levels of physico-chemical parameters of the brackish water system in the wet season-contd.

\begin{tabular}{|c|c|c|c|c|c|c|c|}
\hline $\begin{array}{l}\text { Sample } \\
\text { Location }\end{array}$ & $\begin{array}{l}\text { Total Alkalinity } \\
(\mathrm{mg})\end{array}$ & $\begin{array}{l}\text { Biological Oxygen } \\
\text { Demand ( } m g L)\end{array}$ & $\begin{array}{l}\text { Chemical Oxygen } \\
\text { Demand }(m g L)\end{array}$ & $\begin{array}{l}\text { Dissolved } \\
\text { Oxygen (mgL) }\end{array}$ & $\begin{array}{l}\text { Total Suspended } \\
\text { Solids (mg L) }\end{array}$ & Turbidity (NTU) & $\begin{array}{l}\mathrm{SiO}_{3}{ }^{2-} \\
(\mathrm{mg} \mathrm{L})\end{array}$ \\
\hline $\mathrm{EKC}$ & $93.50=13.94$ & $59.63=9.50$ & $86.40=8.18$ & $3.67=0.50$ & $24.13=2.97$ & $15.50=1.47$ & $2.04=0.60$ \\
\hline $\mathrm{OKC}$ & $114.77=30.00$ & $38.33=1.90$ & $38.40=5.07$ & $3.76=0.54$ & $23.67=2.27$ & $14.63=3.18$ & $2.51=0.12$ \\
\hline $\mathrm{OOC}$ & $128.30=4.78$ & $35.53=0.75$ & $42.37=3.88$ & $3.65=0.99$ & $29.67=5.27$ & $16.70=1.25$ & $2.71=0.26$ \\
\hline OBR & $103.73=14.46$ & $37.13=6.03$ & $46.70=2.86$ & $3.62=0.19$ & $10.13=0.40$ & $7.37=1.53$ & $2.63=0.56$ \\
\hline OGR & $78.60=59.93$ & $33.43=5.17$ & $34.07=3.31$ & $3.91=0.78$ & $17.80=0.50$ & $11.40=1.10$ & $2.46=0.45$ \\
\hline GAC & $112.87=9.87$ & $48.17=13.71$ & $54.80=39.03$ & $4.06=0.51$ & $13.00=1.54$ & $7.70=0.75$ & $2.56=0.39$ \\
\hline $\mathrm{IBC}$ & $123.57=1.50$ & $23.20=6.43$ & $24.60=4.13$ & $3.68=0.47$ & $9.23=1.03$ & $13.83=0.45$ & $2.37=0.54$ \\
\hline OTR & $138.47=45.60$ & $22.53=1.68$ & $25.70=2.52$ & $4.40=0.49$ & $4.67=3.43$ & $5.20=0.50$ & $2.75=0.13$ \\
\hline $\mathrm{OAC}$ & $92.27=11.35$ & $11.20=1.65$ & $15.07=1.27$ & $3.69=0.77$ & $3.70=0.69$ & $2.90=0.62$ & $3.41=0.65$ \\
\hline Range & $(6.50-190.00)$ & $(10.10-69.30)$ & $(10.40-95.70)$ & $(2.53-4.75)$ & $(2.30-33.10)$ & $(2.20-18.30)$ & $(0.11-3.97)$ \\
\hline Ov.mean $=\mathrm{Sd}$ & $104.72=34.08$ & $35.42=14.72$ & $43.39=23.21$ & $3.77=0.57$ & $14.70=8.69$ & $10.67=4.66$ & $2.39=0.83$ \\
\hline
\end{tabular}

Table 4b Mean levels of physico-chemical parameters of the brackish water system in the wet season-contd.

\begin{tabular}{|l|l|l|l|l|l|l|l|}
\hline $\begin{array}{l}\text { Sample } \\
\text { location }\end{array}$ & $\begin{array}{l}\mathrm{NO}_{3}{ }^{-} \\
(\mathrm{mg} / \mathrm{L})\end{array}$ & $\begin{array}{l}\mathrm{SO}_{4}{ }^{2-} \\
(\mathrm{mg} / \mathrm{L})\end{array}$ & $\begin{array}{l}\mathrm{PO}_{4}{ }^{3-} \\
(\mathrm{mg} / \mathrm{L})\end{array}$ & $\begin{array}{l}\mathrm{Ca}^{2+} \\
(\mathrm{mg} / \mathrm{L})\end{array}$ & $\begin{array}{l}\mathrm{Mg}^{2+} \\
(\mathrm{mg} / \mathrm{L})\end{array}$ & $\begin{array}{l}\mathrm{Na}^{+} \\
(\mathrm{mg} / \mathrm{L})\end{array}$ & $\begin{array}{l}\mathrm{K}^{+} \\
(\mathrm{mg} / \mathrm{L})\end{array}$ \\
\hline EKC & $0.02 \pm 0.01$ & $18.47 \pm 3.14$ & $0.48 \pm 0.38$ & $24.78 \pm 1.46$ & $3.88 \pm 1.88$ & $13.92 \pm 6.53$ & $6.31 \pm 0.24$ \\
\hline OKC & $1.09 \pm 0.58$ & $25.00 \pm 0.89$ & $0.89 \pm 1.16$ & $49.66 \pm 13.17$ & $6.58 \pm 3.25$ & $14.99 \pm 4.71$ & $12.91 \pm 4.26$ \\
\hline OOC & $1.07 \pm 0.17$ & $23.60 \pm 2.74$ & $0.20 \pm 0.01$ & $57.56 \pm 3.61$ & $6.00 \pm 2.70$ & $14.61 \pm 5.26$ & $13.72 \pm 4.40$ \\
\hline OBR & $1.04 \pm 015$ & $22.67 \pm 0.40$ & $0.15 \pm 0.05$ & $56.26 \pm 3.68$ & $6.16 \pm 2.83$ & $14.88 \pm 5.05$ & $13.82 \pm 3.40$ \\
\hline OGR & $1.24 \pm 0.24$ & $23.30 \pm 1.64$ & $0.38 \pm 0.31$ & $56.81 \pm 5.43$ & $6.72 \pm 3.14$ & $15.94 \pm 5.13$ & $12.74 \pm 5.80$ \\
\hline GAC & $1.33 \pm 0.61$ & $22.87 \pm 1.16$ & $0.19 \pm 0.05$ & $48.33 \pm 14.17$ & $6.15 \pm 3.73$ & $14.94 \pm 5.08$ & $12.13 \pm 5.34$ \\
\hline IBC & $1.11 \pm 0.34$ & $20.93 \pm 0.85$ & $0.38 \pm 0.29$ & $57.66 \pm 2.65$ & $5.72 \pm 3.56$ & $14.79 \pm 5.02$ & $12.79 \pm 5.88$ \\
\hline OTR & $1.04 \pm 0.37$ & $24.00 \pm 1.01$ & $0.23 \pm 0.05$ & $56.34 \pm 3.82$ & $5.37 \pm 3.37$ & $14.93 \pm 5.96$ & $12.66 \pm 5.23$ \\
\hline OAC & $0.55 \pm 0.20$ & $23.47 \pm 4.02$ & $0.18 \pm 0.05$ & $56.36 \pm 4.74$ & $5.82 \pm 3.08$ & $14.36 \pm 5.44$ & $11.42 \pm 4.63$ \\
\hline $\begin{array}{l}\text { Range } \\
\text { Ov.mean } \pm \text { Sd }\end{array}$ & $(\mathrm{BDL}-1.96)$ & $(10.70-27.70)$ & $(0.04-2.23)$ & $(1.57-60.74)$ & $(0.72-8.88)$ & $(6.01-18.93)$ & $(1.50-16.48)$ \\
\hline
\end{tabular}

Mean $\mathrm{pH}$ in the dry season was $7.47 \pm 0.19$. In the wet season, it was $6.42-8.20$ and the overall mean was $744 \pm 0.52$. Salt intrusion at all stations was evident with very high levels of salinity, producing a brackish condition all over. Mean temperature was $27.18 \pm 0.62$ in the dry season, while in the wet season, it was $27.08 \pm$ 0.43 . There was no significant change in temperature $(\mathrm{p}>0.05)$. Total dissolved solids (TDS) ranged from 445 $35,700 \mathrm{ppm}$ in the dry season with an overall mean level of $27,797.67 \pm 10,786.48$. In the wet season, it was from $234-37,100 \mathrm{ppm}$ with a mean level of 24,702.87 \pm 11,003.99. Salinity levels ranged from 226 - 27,600 ppm with a mean level of $13,791.47 \pm 5,333.83$. In the wet season, the range was $127-17,900 \mathrm{ppm}$ with a mean level of $12,776.60 \pm 5,032.70$. Conductivity levels in the dry season ranged from 789-67,900 $\mu \mathrm{scm}^{-1}$ with a mean level of $53,532.50 \pm 29,657.89$. In the wet season the ranged was from $430-67,300 \mu \mathrm{scm}^{-1}$ with a mean level of $48,837 \pm 18,998.03$. Seasonal change was not significant $(\mathrm{p}>0.05)$. 
Levels of hardness $(\mathrm{Ca}+\mathrm{Mg})$ ranged from $9.12-191.29 \mathrm{ppm}$ with a mean level of $145.45 \pm 54.25$ in the dry season. In the wet season, the range was $8.42-189.29 \mathrm{ppm}$ with a mean level of $144.18 \pm 59.26$. Seasonal variation was insignificant ( $p>0.05$ ) on the `combined data of $\mathrm{Ca}$ and $\mathrm{Mg}$. However, $\mathrm{t}$-test on each of $\mathrm{Ca}$ and $\mathrm{Mg}$ data indicated $\mathrm{Mg}$ seasonally variable $(\mathrm{p}<0.05)$. Levels of total alkalinity in the dry season ranged from 6.90-132 ppm with a mean of $89.81 \pm 39.53$. In the wet season, it was from 6.50-190 ppm with a mean of $104.72 \pm 34.08$. Seasonal difference was significant $(\mathrm{p}<0.05)$. Levels of total suspended solids (TSS) ranged in the dry season from 2.90-38.59 ppm with a mean of $16.14 \pm 10.83$, whereas in the wet season, the range was $2.30-33.10 \mathrm{ppm}$ with a mean of $14.70 \pm 8.69$. Seasonal difference was insignificant $(\mathrm{p}>0.05)$. Turbidity levels ranged from $3.20-22.80 \mathrm{NTU}$ in the dry season with a mean level of $13.04 \pm 5.84$. In the wet season, it ranged from 2.20-18.30 NTU with a mean level of $10.67 \pm 4.66$. Seasonal variation was not significant $(\mathrm{P}>0.05)$.

Biological oxygen demand (BOD) levels ranged from 10.60 - $77.30 \mathrm{ppm}$ with a mean of $37.35 \pm 20.20$ in the dry season. In the wet season, the range was from $10.10-69.30 \mathrm{ppm}$ with a mean of $35.42 \pm 14.72$. Chemical oxygen demand (COD) ranged from $16.10-102.80 \mathrm{ppm}$ with a mean level of $45.43 \pm 24.92$ in the dry season. In the wet season, the range was from $10.40-95.70 \mathrm{ppm}$ with a mean of $43.39 \pm 23.21$. Dissolved oxygen (DO) levels ranged in the dry season from $2.28-4.72 \mathrm{ppm}$ with a mean of $3.79 \pm 0.64$. In the wet season, the range was from $2.53-4.75 \mathrm{ppm}$ with a mean of $3.77 \pm 0.57$.

Levels of silicates in the dry season ranged from $0.01-3.25 \mathrm{ppm}$ with a mean of $2.48 \pm 0.87$, while in the wet season, the range was from $0.11-3.97 \mathrm{ppm}$ with a mean of $2.39 \pm 0.83$. Levels of nitrate in the dry season ranged from below detection limits (BDL) to1.74 ppm with a mean of $0.98 \pm 0.55$. In the wet also, it ranged from BDL to1.96 ppm with a mean of $0.88 \pm 0.53$. Sulphate levels in the dry season ranged from $10.70-$ $28.70 \mathrm{ppm}$ with a mean of $23.13 \pm 3.83$. In the wet season, the range was from $10.70-27.70 \mathrm{ppm}$ with a mean of $21.70 \pm 3.95$. Phosphate levels in the dry season ranged from $0.02-2.13$ ppm with a mean of $0.39 \pm 0.52$. In the wet season, the range was from $0.04-2.23 \mathrm{ppm}$ with a mean of $0.34 \pm 0.41$. Seasonal levels of these nutrient were however comparable ( $\mathrm{p}>0.05$ ).

Sodium levels in the dry season ranged from $7.00-11.43$ ppm with a mean of $9.87 \pm 1.08$. In the wet season, the range was from $6.01-18.93 \mathrm{ppm}$ with a mean of $14.36 \pm 4.54$. Seasonal levels differed significantly $(\mathrm{p}<0.05)$ with higher levels in the wet season. Potassium levels in the dry season ranged from $2.14-9.97 \mathrm{ppm}$ with a mean of 7.58 \pm 2.13 . In the wet season, the range was from $1.50-16.48 \mathrm{ppm}$ with a mean of $11.18 \pm 4.99$. Seasonal variation was significant $(\mathrm{p}<0.05)$. In summary, Total alkalinity (TA), $\mathrm{Mg}^{2+}, \mathrm{K}^{+}$, and $\mathrm{Na}^{+}$revealed significant $(p<0.05)$ seasonal variations with respect to higher values in the wet season.

Tables $5 \mathrm{a}$ and $5 \mathrm{~b}$ show the matrices of correlation coefficients between trace metals and physicochemical parameters measured in surface water of Bonny River and creeks around Okrika. Some significant correlation coefficients $/ \mathrm{r} /$ were seasonal.

Table 5a Correlation matrices: Trace metals versus physicochemical parameters in the dry season

\begin{tabular}{|l|l|l|l|l|l|}
\hline & $\mathrm{Hg}$ & $\mathrm{Pb}$ & $\mathrm{Ni}$ & $\mathrm{V}$ & $\mathrm{Cd}$ \\
\hline $\mathrm{pH}$ & - & 0.099 & 0.114 & 0.544 & 0.097 \\
\hline Temperature & - & $-0.411^{*}$ & 0.236 & -0.088 & -0.219 \\
\hline TDS & - & 0.297 & -0.228 & 0.255 & 0.112 \\
\hline Salinity & - & 0.282 & -0.231 & 0.232 & 0.123 \\
\hline Conductivity & - & 0.243 & -0.212 & 0.227 & 0.130 \\
\hline $\mathrm{TH}$ & - & 0.353 & -0.261 & 0.314 & 0.119 \\
\hline $\mathrm{TA}$ & - & 0.419 & -0.241 & -0.048 & 0.153 \\
\hline $\mathrm{BOD}$ & - & $-0.298^{*}$ & -0.018 & -0.453 & -0.153 \\
\hline $\mathrm{COD}$ & - & -0.270 & -0.062 & -0.538 & -0.132 \\
\hline $\mathrm{DO}$ & - & 0.330 & 0.160 & 0.655 & 0.142 \\
\hline $\mathrm{TSS}^{\mathrm{Turbidity}}$ & - & -0.117 & -0.348 & -0.627 & -0.223 \\
\hline $\mathrm{SiO}_{3}{ }^{-2}$ & - & -0.013 & -0.259 & -0.333 & -0.223 \\
\hline $\mathrm{NO}_{3}{ }^{2-}$ & - & -0.250 & 0.274 & 0.102 \\
\hline $\mathrm{SO}_{4} \mathrm{PO}_{4}{ }^{-2}$ & - & 0.124 & 0.007 & 0.271 & 0.238 \\
\hline $\mathrm{Ca}^{2+}$ & - & 0.364 & -0.044 & 0.257 & 0.127 \\
\hline $\mathrm{Mg}^{2+}$ & - & -0.020 & -0.183 & $0.819^{*}$ & $0.409^{*}$ \\
\hline $\mathrm{Na}^{+}$ & - & $0.621 * *$ & -0.012 & 0.136 \\
\hline $\mathrm{K}^{+}$ & - & 0.231 & -0.251 & 0.002 & -0.022 \\
\hline $\mathrm{O}^{+*}$ & - & -0.137 & 0.021 & 0.214 & 0.177 \\
\hline
\end{tabular}

$* \mathrm{p}<0.05 * * \mathrm{p}<0.01 \quad \bullet \quad \mathrm{TA}$ - total alkalinity $\quad \mathrm{TH}$ - total hardness In the dry season, significant correlation coefficients were those of $\mathrm{Pb} / \mathrm{temp} ; \mathrm{Pb} / \mathrm{BOD} ; \mathrm{Pb} / \mathrm{PO}_{4}{ }^{3-} ; \mathrm{V} / \mathrm{PO}_{4}{ }^{3-} ; \mathrm{Cd} / \mathrm{PO}_{4}{ }^{3-}{ }^{-}(\mathrm{p}<0.01,0.01 ; 0.05 ; 0.01$; $0.01)$. Significant metal/metal correlation coefficient was also found for $\mathrm{Ni} / \mathrm{Pb}(\mathrm{p}<0.05)$ in this season. 
Seasonal Diagenetic Changes in Trace Metals Levels of a Brackish Water System in the Niger ....

Table 5b Correlation matrices: Trace metals versus physicochemical parameters in the wet season

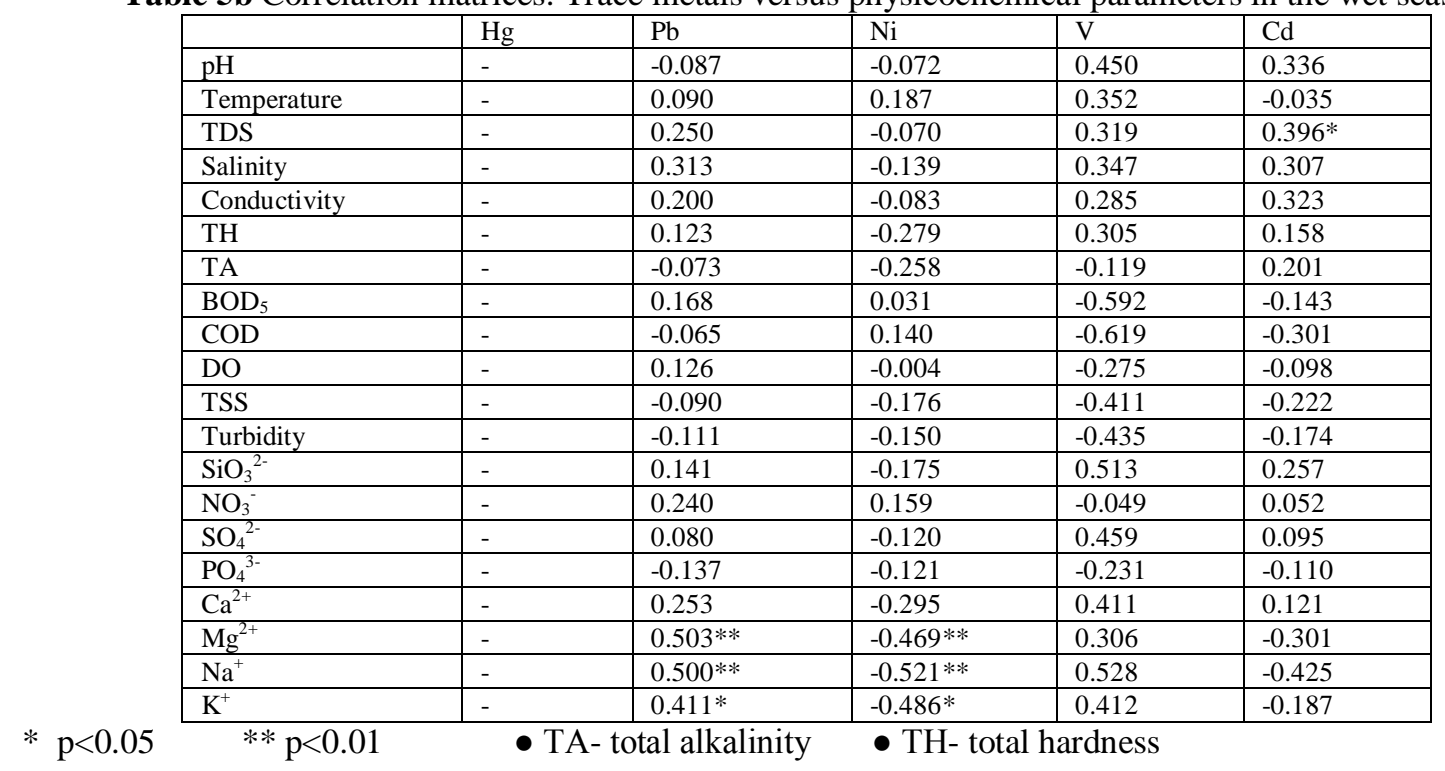

In the wet season, the significant correlations were $\mathrm{Pb} / \mathrm{Mg}^{2+} ; \mathrm{Pb} / \mathrm{Na}^{+} ; \mathrm{Pb} / \mathrm{K}^{+} ; \mathrm{Ni} / \mathrm{Mg}^{2+} ; \mathrm{Ni} / \mathrm{Na}^{+} ; \mathrm{Cd} / \mathrm{Na}^{+.}$and Cd/TDS $\quad(\mathrm{p}<0.05 ; 0.05 ; 0.01 ; 0.01 ; 0.01 ; 0.01 ; 0.01 ; 0.01)$. However, a combination of both seasons revealed many pairs.

\section{Discussion}

Sampling in dry and wet season was to investigate seasonal variabilities of trace metal levels and assess the contribution of runoff water toward trace metal enrichment. It is also to investigate seasonal changes in levels of some water chemical parameters and how these changes affect the levels of trace metals in water.

The use of APDC/MIBK chelation/extraction system was to (i) minimize the interference of major cations that scatter flame, and (ii) to concentrate the metals and increase sensitivity. For any technique to be of value, it is essential that standards closely resemble the samples with respect to the concentration range of analyte(s) and the matrix of the sample. Thus, standard solutions were made to undergo the same procedure as the samples. Such technique tends to minimize matrix differences between samples and standards and the errors in determination that could arise from such effect. It also compensates for lapses in the efficiency of the analytical procedure.

Wastes entering aquatic systems go into the ecosystem. The response of an aquatic system to waste input is a function of the characteristics of the ecosystem, the nature, quality and quantity of wastes (EPA, 1976). The capacity of any particular aquatic system to transform wastes without damage to the ecosystem (selfpurification) is a function of the complexity of such environmental factors as the water flow velocity, volume of water, bottom contour, rate of water exchange, currents, depth, light penetration and temperature, as well as reaeration capacity and chemical and biological interaction within the system (EPA, 1976).

Most flowing systems have greater re-aeration capacity than standing waters, and flowing system are "open systems" with continual renewal of water; whereas standing systems such as lagoons are "closed systems", and act as "traps" for pollutants. Thus, the system studied which could be considered 'open', has high capacity for self-purification due to oxygen diffusion at the surface, together with dilution, which enables the water to assimilate polluting discharges. Consequently, the levels of the metals were low in spite of heavy loadings from human and sundry sources. The generally low levels are also attributable to the brackish condition of the system which may increases the volatilities of many elements, and analyte loss may occur during the pyrolysis step (Haarvad, 2003).

The absence of significant seasonal differences $(p>0.05)$ in the concentrations of some of the trace metals except $\mathrm{Pb}$ and $\mathrm{Cd}$, and higher values in the wet season except $\mathrm{Ni}$ (Table 2), may be explained as resulting from high flushing and dilution rates during the rains, in addition to the associated velocity of the system or "solution effect" consequent upon a process whereby ions bound in previous semi-dry land by decaying macrophytes get dissolved as water levels increased with inundation of fringing swamps and riparian zones (Welcome, 1986; King and Nkanta, 1991). Owing to the seasonal influence which brought about elevated levels of $\mathrm{Pb}$ and $\mathrm{Cd}$ in the wet season, the US EPA (US EPA, 2000) limits for marine/brackish and freshwater are slightly exceeded as presented in table 6 . 
Table 6 US EPA maximum allowable levels in water compared with mean levels of the brackish water system

\begin{tabular}{|l|l|l|l|}
\hline Metal & $\begin{array}{l}\text { Bonny River and Creeks around } \\
\text { Okrika }(\mathrm{ppb})\end{array}$ & \multicolumn{2}{|l|}{ USEPA maxima (ppb) } \\
\cline { 3 - 4 } & & \multicolumn{1}{|c|}{ Marine } & Freshwater \\
\hline $\mathrm{Hg}$ & $\mathrm{ND}$ & $<1.0$ & $<1.0$ \\
\hline $\mathrm{Pb}$ & 21.69 & $1.0-7.0$ & $<1.0-7.0$ \\
\hline $\mathrm{Ni}$ & 38.84 & $<100$ & $<100$ \\
\hline $\mathrm{V}$ & 0.14 & - & - \\
\hline $\mathrm{Cd}$ & 4.45 & $<0.5-5.0$ & $<0.2-2.8$ \\
\hline
\end{tabular}

ND: Not Determined

On the other hand, in the dry season, the inflow of water is at minimal level, and under such condition, sedimentation would become more efficient since water is only disturbed by tidal currents. The significant correlations between $\mathrm{PO}_{4}{ }^{3-}$ and $\mathrm{Pb}, \mathrm{V}$ and $\mathrm{Cd}$ in this season (Table 5a) suggest that these metals are present in their phosphates probably as particulates. In the wet season (Table 5b), the correlations between major metal cations and the trace metals, $\mathrm{Pb}$ and $\mathrm{Ni}$ are however, not easily explicable, but that of $\mathrm{Cd}$ and TDS is an indication that most of the cadmium is in solution. The negatively significant correlations between the trace metals and physicochemical parameters in both seasons may suggest inhibitive tendencies of these water parameters towards mobilization of these metals to the water column (Marcus et. al., 2013).

\section{Conclusion}

In the studied brackish water system, the interplay of chemical and physical parameters has resulted in seasonal variations in the levels of both trace metals and physicochemical parameters. The correlations between trace metals and physicochemical parameters have also been observed to reveal seasonal diagenetic changes. Apart from direct discharge of industrial and domestic wastes, the immense volume of storm water runoff and river waters entering the water, and perhaps hydrodynamics and the characteristic features of the area that are inexplicable, may have played significant roles in transporting metals originating from wastes discharge on land and in small streams, especially during the rains. This phenomenon resulted in elevated levels of lead and cadmium in the water column in wet season.

\section{References}

[1]. Abam, A. (1999) The Okrika Kingdom: An Analysis of the Dynamics of Historical Events. $1^{\text {st }}$ Ed. Springfield Publishers, Owerri, Nigeria, pp. 2-12.

[2]. Akcay, H., Oguz, A. and Karapire, C. (2003) Study of heavy metal pollution and speciation in Buyak Menderes and Gediz river sediments, Water Res, 37, 813- 822.

[3]. APHA (1998) Standard methods for the examination of water and wastewater $20^{\text {th }}$ edition. American Public Health Association, American Water Works Association and Water Environment Federation (APHA-AWWA-WEF), Published by The American Public Health Association, Washington D.C.

[4]. APHA (1992) Standard methods for the examination of water and wastewater, $18^{\text {th }}$ edition. American Public Health Association, American Water Works Association, Water Pollution Control Federation (APHA-AWWA-WPCF). Published by the American Public Health Association, Washington D.C, USA.

[5]. ASTM (2005) Annual book for ASTM standards. American Society for Testing Materials, p.285.

[6]. Biney, C., Amuzu, A.T., Calamari, D., Kaba, N., Mbome, I.L., Naeve, H., Ochumba, P.B.O., Osibanjo, O., Radegonde, V. and Saad, M.A.H. (1994) Review of pollution in the African aquatic environment, FAO, Rome.

[7]. Boyd, C.E. and Tucker, C.S. (1998). Pond aquaculture water quality management., Kluwer Academic Publishers, London.

[8]. Cantillo, A. and Calder, J. (1990) Reference material for marine science. Fresenius Journal of Analytical Chemistry 338:380-382.

[9]. Chindah, A.C., Braide, S.A., Sibeudu, O.C. (2004) Distribution of hydrocarbons and heavy metals in sediment and a crustacean shrimps-Penaeus notialis from the Bonny/New Calabar River Estuary, Niger Delta. A JEAM-RAGEF 9:1-17

[10]. Dassenakis, M., Scoullos, M. and Gaitis, A. (1997) Trace metals transport and behaviour in the Mediterranean estuary of Archeloos river, Mar. Pollut. Bull., 34, 103-111.

[11]. EPA (1976) Quality criteria for water, US EPA, 440/9-76-023; Environmental Protection Agency, Washington DC.

[12]. Frank, L and Cross, P.E. (1974) Management primer on water pollution control. Technomic Publishing Company, Inc., West Port. pp: $23-27$.

[13]. Garg, R.K., Rao, R.J., Uchchariya, D.; Shukla G. and Saksena, D.N. (2010) Seasonal variations in water quality and major threats to Ramsagar reservoir, India. African Journal of Environmental Science and Technology (AJEST) 4(2): 061-076.

[14]. Haavard H. (2003) Trace elements determination AAS. Norwegian Institute for Water Research, HORIZONTAL-20. p 10

[15]. Kabata-Pendias, A. and Pendias, H. (1992) Trace elements in soils and plants, CRS Press, Boca Raton.

[16]. King, R.P and Nkanta, N.A. (1991) The status and seasonality in the physicochemical hydrology of a Nigerian rain forest pond. The Japanese Jour. of Limnology 52:1-12.

[17]. Iwashita, M. and Shimamura T. (2003) Long-term variations in dissolved trace elements in the Sagami River and its tributaries (upstream area), Japan, The Science of the Total Environment, 312, 167-179.

[18]. Jarup, L (2003) Hazards of heavy metal contamination. Braz. Med. Bull. 68:167- 182.

[19]. Marcus, A.C., Okoye, C.O.B.and Ibeto, C.N.(2013) Environmental pollution quality assessment of Bonny River and Creeks around Okrika Rivers State, Nigeria. International Journal of Applied Environmental Sciences 8 (1):1-11

[20]. Miller, C.V., Foster, G.D. and Majedi, B.F. (2003) Baseflow and stormflow metal fluxes from two small agricultural catchments in the coastal plain of Chesapeake Bay Basin, United States, Appl. Geochem., 18, 483-501.

[21]. NAE DEGDIST. (1933) 7/5/6:Porter, J.C. Intelligence Report on the Okrika clan, para.11. 
[22]. NESREA (2009) National environment (wetlands, rivers banks and lake shores protection) regulation. Published by National Environmental Standards and Regulations Enforcement Agency (Establishment) Act, 2007, No.58, Vol.96

[23]. Nicolau, R., Galera-Cunha, A. and Lucas, Y. (2006) Transfer of nutrients and labile metals from the continent to the sea by a small Mediterranean river, Chemosphere, 63, 469-476.

[24]. Okoye, B.C.O. (1991) Nutrients and selected chemical analysis in the Lagos Lagoon surface water. Intern. J. Environmental studies 38: $131-136$.

[25]. Otokunefor, T.V. and Obiukwu, C. (2005) Impact of refinery effluent on the physicochemical properties of a water body in the Niger Delta. Applied Ecology and Environmental Research 3(1): 61-72.

[26]. Osmond, D.L., Line, D.E., Gale, J.A., Gannon, R.W., Knott, C.B., Bartenhagen, K.A., Turner, M.H., Coffey, S.W., Spooner, J., Wells, J., Walker, J.C., Hargrove, L.L., Foster, M.A., Robillard, P.D. and Lehning, D.W. (1995) Water, Soil and HydroEnvironmental Decision Support System, URL:www.water.ncsu.edu/watersheds/info /hmetals.html

[27]. Pan, Y. and Brugam, R.B. (1997). Human disturbance and tropic status changes in Crystal Lake, McHenry County, Illinois, USA. J. Paleolimnology 17:369-376.

[28]. Sithik, A.M.A., Thirumaran, G., Arumugam, R.; Kannan R.R.R. and Anontharaman, P. (2009) Physico-chemical parameters of Holy Places Agnitheerthan and Kothandaramar Temple; South coast of India. Amer ican-Eurasian Journal of Scientific Research 4 (2): 108-116.

[29]. Silva, A.L.O.; Barrocas, P.R.G.; Jacob, S.C.; Moreira, J.C. (2005) Dietary intake and health effects of selected toxic elements. Braz. J. Plant Physiol. 17:79-93.

[30]. United Nation Environmental Protection (UNEP)-Industry and environmental overview series (1992) Environmental management practices in Oil refineries: United nation environmental Program. pp 8-52.

[31]. US EPA (2000) Nation water quality inventory: 1998 Report to congress. www.epa.gov/305b/98report. Cast updated October 5, 2000 .

[32]. Welcome, R.L. (1986) The Niger River system. Longman Group Ltd, London. pp 9-23.

[33]. Wilcox, B.H.R. (1985). Angiosperm flora of the Niger Delta Mangal: A taxanomic review. Proc. Workshop on the Niger Delta Mangrove Ecosystem, Port Harcourt, 19-23 May, 1980, p.190

[34]. Zarazua, G., Ávila-Pérez, P., Tejeda, S., Barcelo-Quintal, I. and Martínez, T. (2006) Analysis of total and dissolved heavy metals in surface water of a Mexican polluted river by Total Reflection X-ray Fluorescence Spectrometry, Spectrochimica Acta Part B: Atomic Spectroscopy, 61, 1180-1184.

[35]. Zar, J.H. (1996) Biostatistics analysis. Prentice Hall, Upper Saddle River. 662p. 